Santa Clara Law

Santa Clara Law Digital Commons

\title{
A Constitutional Analysis of Parents Involved in Community Schools v. Seattle School District No. 1 and Voluntary School Integration Policies
}

Angelo N. Ancheta

Santa Clara University School of Law, aancheta@scu.edu

Follow this and additional works at: http://digitalcommons.law.scu.edu/facpubs

Part of the Civil Rights and Discrimination Commons, and the Constitutional Law Commons

Recommended Citation

10 Rutgers Race \& L. Rev. 297 (2008-2009)

This Article is brought to you for free and open access by the Faculty Scholarship at Santa Clara Law Digital Commons. It has been accepted for inclusion in Faculty Publications by an authorized administrator of Santa Clara Law Digital Commons. For more information, please contact sculawlibrarian@gmail.com. 


\section{A Constitutional Analysis of}

\section{Parents Involved in Community}

Schools v. Seattle School District

\section{No. 1 and Voluntary School Integration Policies}

Angelo N. Ancheta ${ }^{\dagger}$

\section{Introduction}

On June 28, 2007: a sharply divided United States Supreme Court invalidated student assignment plans in Seattle, Washington and Louisville, Kentucky that were designed to promote racial diversity and to address racial isolation in $\mathrm{K}-12$ education. By a 5-to-4 vote in Parents Involved in Community Schools v. Seattle School District No. I and McFarland v. Jefferson County Board of Education, the Court struck down voluntary integration plans under the "strict scrutiny" standard applied to race-conscious policies challenged under the Equal Protection Clause of the Fourteenth Amendment, and ruled that the plans were not narrowly tailored to the interests asserted by the school districts. ${ }^{1}$

†. Assistant Professor of Law, Santa Clara University School of Law. E-Mail: AAncheta@scu.edu. Address: Santa Clara University School of Law, $500 \mathrm{El}$ Camino Real, Santa Clara, California 95053. This paper was prepared for the Charles Hamilton Houston Institute for Race and Justice at Harvard Law School (September 2007).

1. 127 S. Ct. 2738 (2007). 
The Supreme Court's ruling in Parents Involved in Community Schools is disappointing and troubling for a number of reasons. First, the ruling significantly limits the use of race by school districts voluntarily seeking to integrate their schools, at a time when racial isolation and resegregation are increasing nationwide. Second, when viewed in the context of the Court's landmark decision in Brown v. Board of Education, the ruling marks a sharp turn in the Court's historical commitment to addressing racial segregation in public schools. Third, the ruling sends a strong signal that a majority of the Court's current membership is highly skeptical of race-conscious policies designed to promote equality and the integration of public institutions. Indeed, four members of the Court, including its two newest members, appear ready to strike down any deployment of race designed to advance equal opportunity.

Nevertheless, because of the voting alignment of the Justices in these cases and the limits of the Court's rulings, school districts retain the ability to employ race-conscious measures designed to integrate their schools. Five of the Justices endorsed the compelling interests in reducing racial isolation and in promoting educational diversity in elementary and secondary schools, and the opinions of those Justices provide guidance on how school districts might proceed in designing constitutionally permissible policies. Moreover, the Supreme Court as a whole made clear that Grutter v. Bollinger, its 2003 ruling upholding the use of race to promote student body diversity in higher education, is good law.

This paper examines the Seattle and Louisville cases and discusses their impact on $\mathrm{K}-12$ education and constitutional doctrine. The analysis is divided into three parts. Part I examines the Justices' opinions in Parents Involved in Community Schools 
and discusses the constitutional boundaries for voluntary raceconscious integration policies established by the Court. Part II discusses the implications of the cases in creating and implementing $\mathrm{K}-12$ policies designed to avoid racial isolation and to promote educational diversity. Part III assesses the impact of the cases on equal protection doctrine and race-conscious policy making more generally.

\section{The Constitutional Limits of Race-Conscious Integration Policies: Understanding the Parents Involved in Community Schools Opinions}

Because the voting alignment and reasoning of the Justices in Parents Involved in Community Schools are critical in determining controlling constitutional principles, it is necessary to examine the Justices' separate opinions and to analyze how the opinions interrelate. ${ }^{2}$ Justice Anthony Kennedy joined Chief Justice John G. Roberts, along with Justices Samuel Alito, Antonin Scalia, and Clarence Thomas, to form the five-member majority to strike down the Seattle and Louisville plans. However, Justice Kennedy did not join key passages of Chief Justice Roberts' plurality opinion and made clear in his opinion that he flatly disagreed with important elements of the plurality's reasoning. In addition, a different majority of the Justices, composed of Justice Kennedy and dissenting Justices Stephen Breyer, Ruth Bader Ginsburg,

2. Chief Justice Roberts announced the judgment of the Court and his opinion was joined in full by Justices Alito, Scalia, and Thomas. Justice Kennedy concurred in the judgment and joined Parts I, II, III-A, and III-C of Chief Justice Roberts' four-part plurality opinion. Justice Thomas issued a separate concurring opinion. Justice Breyer, joined by Justices Ginsburg, Souter, and Stevens, issued a dissenting opinion. Justice Stevens also issued a dissenting opinion. 
David Souter, and John Paul Stevens, endorsed the school districts' compelling interests in avoiding racial isolation and in promoting diversity, and thus have provided bases for educational policy makers to employ race-conscious policies in the future and still comply with the Equal Protection Clause.

\section{A. Chief Justice Roberts' Opinion}

Justice Kennedy joined Parts I, II, III-A and III-C of Chief Justice Roberts' four-part plurality opinion in Parents Involved in Community Schools; these parts of the Roberts' opinion constitute a formal opinion of the Court. Part I of the Roberts' opinion discusses the factual and procedural context of the two cases and examines the basic mechanics of the Seattle and Louisville plans. ${ }^{3}$ Part II addresses a threshold issue involving whether the Court had jurisdiction in the Seattle case because of the plaintiffs' lack of standing to sue; the Court concluded that it did have jurisdiction. ${ }^{4}$ Part III-A discusses the standard of review and the applicability of the Court's prior ruling in Grutter v. Bollinger. ${ }^{5}$ Part III-C focuses on the question of whether the Seattle and Louisville plans are narrowly tailored and provides reasoning for the Court's invalidation of the two plans. ${ }^{6}$

Parts III-B and IV of the Roberts opinion examine the school districts' justifications for their policies and contain arguments designed to counter the dissenting opinions of Justice Breyer and Justice Stevens. While they do not reflect an opinion of the Court, these parts of the Roberts opinion are significant because
3. 127 S. Ct. at $2746-50$.
4. Id. at 2750-51.
5. Id. at 2751-54.
6. Id. at 2759-61. 
they stand in stark contrast to Justice Kennedy's reasoning in the cases, and, as discussed below, contain startling interpretations of Brown v. Board of Education and equal protection jurisprudence that mark an extreme departure from longstanding interpretations of the Constitution.

\section{Opinion of the Court}

Parts III-A and III-C of the Roberts opinion are central to the Court's holding in Parents Involved in Community Schools. Part III-A confirms that the standard of review in evaluating student assignment policies that classify on the basis of race is strict scrutiny, the most exacting standard of review used by the courts to evaluate policies under the Equal Protection Clause. Under strict scrutiny, the courts ask two questions to assess the ends and the means that underlie a race-conscious policy: (1) Is the goal of the policy sufficiently important to constitute a compelling governmental interest? and (2) is the policy narrowly tailored to that compelling interest? A negative answer to either of these inquiries invalidates a race-conscious policy. Although the Roberts opinion recognized that context matters in strict scrutiny, ${ }^{7}$ the majority did not adjust or relax its strict scrutiny inquiries; nor did the majority extend any deference to the school districts because of the K-12 educational context or because the plans were designed to promote integration and not to subordinate racial minority group members.

7. Id. at 2754 . 


\section{a. Compelling Interest}

The Court concluded in Part III-A of the Roberts opinion that the interests asserted by the school districts to justify their race-conscious policies are distinct from two interests that the Court previously recognized as compelling: (1) remedying the present effects of past discrimination, and (2) promoting student body diversity in higher education. Arguing that an interest in remedying past discrimination was not applicable to the Seattle and Louisville cases, the Court emphasized the distinction between de jure segregation arising through the intentional separation of students by force of law from de facto segregation in which racial isolation results from other factors, such as residential housing patterns and private-sector discrimination. The Louisville schools, the majority argued, had been released in 2000 from a longstanding court order to desegregate their schools. The majority further argued that the Seattle schools had never been "segregated by law" and were not subject to a desegregation decree, notwithstanding extensive evidence of discrimination in local housing and other factors affecting student enrollment, as well as a memorandum of agreement between the school district and the federal Office for Civil Rights to desegregate the schools. ${ }^{8}$

8. See id. at 2752. The Court also dismissed, as dicta, key language from the Court's 1971 decision in Swann v. Charlotte-Mecklenburg Board of Education, which would suggest that school districts could employ race-conscious measures in the absence of de jure segregation and a court order. Id. at n. 10. That language states: "School authorities are traditionally charged with broad power to formulate and implement educational policy and might well conclude, for example, that in order to prepare students to live in a pluralistic society each school should have a prescribed ratio of Negro to white students reflecting the proportion for the district as a whole. To do this as an educational policy is within the broad discretionary powers of school authorities ..." Swann v. Charlotte-Mecklenburg Bd. of Educ., 402 U.S. 1, 16 (1971). 
The majority's analysis also distinguished an educational diversity interest in higher education recognized in Grutterwhere race was but one dimension of a broader student body diversity-from a racial diversity interest used to justify the school districts' student assignment plans: "The Court in Grutter expressly articulated key limitations on its holding-defining a specific type of broad-based diversity and noting the unique context of higher education ...." The Court then declared that, despite the parallels and linkages between $\mathrm{K}-12$ education and higher education, " $\mathrm{t}]$ he present cases are not governed by Grutter."10

Because of this turn in logic, among other reasons, neither Justice Kennedy nor the dissenting Justices agreed with the plurality's subsequent conclusions that Grutter provided no support for the school districts' asserted interests. The Chief Justice's reading of Grutter is indeed inconsistent with key language in the Grutter opinion itself, where the Court stressed the importance of diversity throughout the educational system: in upholding the compelling interest in higher education diversity, the Grutter opinion states that the Court has "repeatedly acknowledged the overriding importance of preparing students for work and citizenship, describing education as pivotal to 'sustaining our political and cultural heritage' with a fundamental role in maintaining the fabric of society." ${ }^{11}$

Because of Justice Kennedy's basic disagreement with Chief Justice Roberts' analysis of the school districts' compelling interest arguments (contained in Part III-B of the Roberts opinion), there

9. Parents Involved in Cmty Sch.,127 S. Ct. at 2754.

10. Id.

11. Grutter v. Bollinger, 539 U.S. 306, 331 (2003) (citing Plyer v. Doe, 457 U.S. 202 (1982)). 
is no holding from the Court addressing whether the school districts' interests in promoting racial diversity and in avoiding racial isolation are compelling. Nor is there a holding by the Court that these interests are not compelling. Instead, the Court's invalidation of the Seattle and Louisville plans turns on the narrow tailoring prong of strict scrutiny.

\section{b. Narrow Tailoring}

The Supreme Court has not established a fixed test for narrow tailoring, but in assessing whether a race-conscious policy is narrowly tailored, the Court typically looks at an array of factors, such as whether a policy is necessary to achieve an asserted goal, whether it is sufficiently flexible, whether it unduly burdens non-minorities, whether race-neutral policies have been considered as alternatives, and whether time limits or periodic reviews lead to a logical endpoint for the policy. ${ }^{12}$ In Part III-C of the Roberts opinion, the majority concludes in summary fashion that the Seattle and Louisville plans are not narrowly tailored for two reasons: first, employing race in student assignments was not necessary to achieve the goal of racial diversity, and second, the school districts failed to show that they had considered adequate race-neutral alternatives.

\section{i. The Seattle and Louisville Plans}

Both school districts operated "controlled choice" policies that employed race as one of multiple factors in deciding whether a student might be assigned to a particular school; in different

12. See Grutter, 539 U.S. at 334-43; United States v. Paradise, 480 U.S. 149 (1987). 
ways, the plans managed student assignments consistent with district-wide demographics and broad numerical goals. ${ }^{13}$ Under the Seattle plan, entering high school students were given a choice to attend any three of the district's ten high schools and to rank them in order of preference. If there were more students who ranked a particular high school first than there were available spaces at the school, the district employed a series of "tiebreakers" to determine whether a student would be assigned to that school. Under an initial tiebreaker, a preference was given to students with a sibling attending an oversubscribed school. Students were then assigned based on their geographic proximity to the school, unless the school was racially imbalanced-i.e., the racial composition of the school's student body differed from the district's average by more than fifteen percentage points. ${ }^{14}$

Under the Louisville plan, which evolved from a courtordered plan that had been in place from 1975 to 2000 to desegregate the Louisville schools, the district employed a broad guideline that every school should seek a black student enrollment ranging from 15 percent to 50 percent. ${ }^{15}$ The guideline was employed to evaluate requests for transfers from students' "resides"

13. The details of the Seattle and Louisville plans are beyond the scope of this Paper. An extensive history and analysis of the plans are contained in Justice Breyer's dissenting opinion, while a more abbreviated analysis is contained in Chief Justice Roberts' plurality opinion. See Parents Involved in Cmty. Sch., 127 S. Ct. 2738 (2007).

14. In 2001-02, the most recent year that the plan was employed, approximately $60 \%$ of the district's roughly 46,000 students were non-white and approximately $40 \%$ were white. Because of residential segregation, over $75 \%$ of the district's minority students live in the southern half of the city, and approximately two-thirds of the white students live in the northern half of the city.

15. During the 2003-04 school year, the Jefferson County Public Schools enrolled approximately 97,000 students, of which approximately $34 \%$ were black and $66 \%$ were "other" (almost all of whom were white). See Parents Involved in Cmty. Sch., 127 S. Ct. at 2749. 
schools-i.e., schools to which students were initially assigned based on geographic residence. When employed, race could "tip the balance" after residence, choice, and all other factors had played a part in assessing the transfer request.

\section{ii. Necessity of the Plans}

The majority concluded in Part III-C of the Roberts opinion that the use of race had only minimal effects on student assignments in the districts, suggesting that the plans were not a necessity and therefore alternative policies would be more effective. The majority found that in the Seattle school district, 307 student assignments were affected by the racial tiebreaker during the 2000-01 school year; the use of race made no difference in over one-third of the assignments affected by the racial tiebreaker; and only 52 students were adversely affected by the tiebreaker, in that they were assigned to a school that had not been listed as a preference and to which they would not have been otherwise assigned. ${ }^{16}$

The majority further found that elementary school students in the Louisville schools had been assigned to their first- or second-choice school 95 percent of the time; that transfers, which constituted five percent of the assignments, were denied only 35 percent of the time; and that presumably an even smaller percentage were denied on the basis of the racial guidelines. ${ }^{17}$ The majority then noted that the racial guidelines would only account for three percent of assignments. The majority went on to conclude: "While we do not suggest that greater use of race would be preferable, the minimal impact of the districts' racial classifications on school enrollment casts doubt on the necessity
16. Id. at 2796 .
17. Id. at 2760 . 
of using racial classifications." 18 In contrast, the majority added, the consideration of race upheld in Grutter "was viewed as indispensable in more than tripling minority representation at the [University of Michigan] law school-from 4 to 14.5\%."19

The majority's discussion of the necessity of the plans is brief. There is no analysis of alternative policies, nor does the majority recognize the actual effects of the plans on promoting diversity and preventing racial isolation. Language accompanying the Court's necessity analysis is particularly telling, however, and seems consistent with the plurality's predisposition to strike down any race-based classification and assignment system: "Classifying and assigning schoolchildren according to a binary conception of race is an extreme approach in light of our precedents and our Nation's history of using race in public schools, and requires more than such an amorphous end to justify it." ${ }^{20}$

In concluding that neither of the policies was a necessity, the Court's analysis also reveals a tension in its narrow tailoring inquiry. In order to comply with prior case law and to avoid other narrow tailoring concerns, the plans intentionally limited race as a factor in student assignments. The relatively mild uses of race employed by the districts were designed to prevent problems of inflexibility or undue burden, but were not sufficient to satisfy the Court's inquiry into necessity. Ironically, the districts were penalized for not using race enough to make a sufficiently meaningful difference in student enrollments.

18. Id. (emphasis in original).

19. Id.

20. Id. 


\section{iii. Race-Neutral Alternatives}

In addition to relying on necessity grounds to invalidate the plans, the majority concluded in Part III-C that the districts failed to satisfy narrow tailoring because they had not engaged in "serious, good faith consideration of workable race-neutral alternatives." 21 The majority ruled that the Seattle school district had rejected several alternative assignment plans with little or no consideration-although Chief Justice Roberts provides no discussion of why the district might have rejected those alternatives as less effective or inferior to the challenged plans. The majority further ruled that the Louisville school district had failed to present evidence that it had considered race-neutral alternatives at all. The long history of court-ordered desegregation in the Louisville schools, which extended over 25 years from 1975 to 2000, appeared to play no role in Chief Justice Roberts' consideration of the need for alternative policies.

\section{Parts III-B and IV of the Roberts Opinion}

Although he voted to strike down the Seattle and Louisville plans on narrow tailoring grounds, Justice Kennedy declined to join Part III-B of Chief Justice Roberts' opinion, which focuses on the compelling interests of the school districts. Justice Kennedy also declined to join Part IV of the Roberts opinion, which, in addressing the dissents' central criticisms, contains remarkable language that attempts to recast Brown v. Board of Education and other leading equal protection cases. Neither Part III-B nor Part IV form part of the opinion of the Court, but they deserve serious attention because of the extremity of many of Chief Justice

21. Id. (quoting Grutter, 539 U.S. at 339). 
Roberts' arguments. They also reflect the views of the Court's two newest members, the Chief Justice and Justice Alito.

\section{a. Part III-B}

In Part III-B of the Roberts opinion, the plurality addresses the school districts' interests in promoting racial diversity and in avoiding racial isolation and resegregation. After decoupling Grutter and the diversity interest in higher education from the K-12 educational context, Chief Justice Roberts does not address the question of whether the school districts' interests achieve the educational and social benefits asserted to flow from racial diversity. Instead, the Chief Justice's opinion recharacterizes the school districts' asserted interests as "racial balancing." His opinion states: "In design and operation, the plans are directed only to racial balance, pure and simple, an objective this Court has repeatedly condemned as illegitimate. The plans are tied to each district's specific racial demographics, rather than to any pedagogic concept of the level of diversity needed to obtain the asserted educational benefits." 22 The Chief Justice's opinion goes on to criticize the districts for not offering sufficient evidence to explain why the level of racial diversity to achieve the asserted educational benefits necessarily coincided with the racial demographics of each district.

Regardless of the strength or appropriateness of the demographic evidence introduced by the districts, the Chief Justice's rhetorical use of the term "racial balancing" effectively severs any meaningful connection between the use of racial demographics and the districts' goals of attaining the benefits of diversity and of avoiding the harms of racial isolation. Once the

22. Id. at 2755 . 
districts' interests were recharacterized as interests in numerical balancing and racial proportionality, the plurality invalidated the districts' interests because of language in prior Supreme Court opinions proposing that "'outright racial balancing' is 'patently unconstitutional."'23 Chief Justice Roberts thus argued that "[a]ccepting racial balancing as a compelling state interest would justify the imposition of racial proportionality throughout American society." ${ }^{24}$

But, as Justice Kennedy and Justice Breyer emphasize in their opinions, the interests of the school districts are not merely designed to promote racial proportionality for proportionality's sake. Instead, they are tied to preventing concrete harms associated with segregated schools and to promoting concrete educational benefits associated with diverse student bodies. The Roberts plurality makes short shrift of the long history of legal precedents dating back to Brown v. Board of Education, where the federal courts imposed strong remedies to address the extensive harms of racially segregated schools. Moreover, the plurality opinion ignores the substantial body of recent social science research demonstrating the harms of racial isolation and resegregation, as well as the educational benefits of racially diverse schools. ${ }^{25}$

\section{b. Part IV}

Part IV is the most provocative and controversial section of Chief Justice Roberts' opinion, and it is extraordinary in its attempt to refashion the legacy of Brown v. Board of Education as one of uncompromising colorblindness. It is not a novel claim

23. Id. at 2757 (quoting Grutter, 539 U.S. at 330).

24. Id.

25. Id. at 2755 . 
to assert that Brown's core norm is an anticlassification principle that prohibits any differential treatment on the basis of race, but such a claim has never enjoyed the support of a majority of the Justices on the Supreme Court - and it still does not. Nonetheless, the Roberts plurality opinion is striking in its rhetoric and its reinterpretation of Brown, and even goes so far as to recast the Brown litigators as champions of absolute race-blindness.

Proposing that "when it comes to using race to assign children to schools, history will be heard," ${ }^{26}$ Chief Justice Roberts' opinion ignores the decades-long history of racial subordination associated with segregated schools and focuses instead on the simple recognition of racial differences as the underlying harm recognized in Brown: "It was not the inequality of the facilities but the fact of legally separating children on the basis of race on which the Court relied to find a constitutional violation in 1954." ${ }^{27}$ And quoting Brown v. Board of Education II, the Court's 1955 opinion on remedying school segregation, the Roberts opinion further states that Brown I "required school districts 'to achieve a system of determining admission to the public schools on a nonracial basis." 28

In determining which side is "more faithful to the heritage of Brown," ${ }^{29}$ the Roberts opinion goes on to quote the Brown plaintiffs' brief, which states in part that "[ $\mathrm{t}]$ he Fourteenth Amendment prevents states from according differential treatment to American children on the basis of their color or race," and to quote from the oral argument of Robert L. Carter, who argued for

26. Id. at 2767.

27. Id.

28. Id. (quoting Brown v. Bd. of Educ. of Topeka, Kan., 349 U.S. 294, 300-01 (1955)).

29. Id. 
the Brown plaintiffs in 1952, for the proposition that "no State has any authority under the equal-protection clause of the Fourteenth Amendment to use race as a factor in affording educational opportunities among its citizens." 30 Then, equating the Brown case with the Seattle and Louisville cases, the Chief Justice goes on to ask, "[w] hat do the racial classifications do in these cases, if not determine admission to a public school on a racial basis?" and then states, "[b]efore Brown, schoolchildren were told where they could and could not go to school based on the color of their skin. The school districts in these cases have not carried the heavy burden of demonstrating that we should allow this once again—even for very different reasons." ${ }^{31}$ Finally, the Chief Justice closes his opinion with the following statement: "The way to stop discrimination on the basis of race is stop discriminating on the basis of race." 32

\section{c. The Kennedy and Dissenters' Responses}

The remarkable language in Parts III-B and Part IV of the Roberts opinion led Justice Kennedy to disavow the plurality's language and analysis. As Justice Kennedy states early in his opinion: "My views do not allow me to join the balance of the opinion by The Chief Justice, which seems to me to be inconsistent in both its approach and its implications with the history, meaning, and reach of the Equal Protection Clause." ${ }^{33}$ Justice Kennedy later states: "parts of the opinion by The Chief Justice imply an all-too-unyielding insistence that race cannot

30. Id. at 2767-68.

31. Id. at 2768.

32. Id.

33. Id. at 2788 (Kennedy, J., concurring in part and concurring in the judgment). 
be a factor in instances when, in my view, it may be taken into account" ${ }^{34}$ and "[t]o the extent the plurality opinion suggests the Constitution mandates that state and local school authorities must accept the status quo of racial isolation in schools, it is, in my view, profoundly mistaken." 35

The dissenting opinions in Parents Involved in Community Schools are even more critical of the plurality, with Justice Stevens stating that " $[t]$ here is a cruel irony in The Chief Justice's reliance on our decision in Brown v. Board of Education" 36 and that " $[\mathrm{t}]$ he Chief Justice rewrites the history of one of this Court's most important decisions." ${ }^{37}$ Justice Breyer's lengthy dissenting opinion contains even more excoriating language:

[The plurality] distorts precedent, it misapplies the relevant constitutional principles, it announces legal rules that will obstruct efforts by state and local governments to deal effectively with the growing resegregation of public schools, it threatens to substitute for present calm a disruptive round of racerelated litigation, and it undermines Brown's promise of integrated primary and secondary education that local communities have sought to make a reality. This cannot be justified in the name of the Equal Protection Clause. ${ }^{38}$

Justice Breyer goes on pointedly to state: "[I]t is a cruel distortion of history to compare Topeka, Kansas, in the 1950's to Louisville and Seattle in the modern day - to equate the plight of Linda Brown (who was ordered to attend a Jim Crow school) to

34. Id. at 2791.

35. Id.

36. Id. at 2797 (Stevens, J., dissenting).

37. Id. at 2798.

38. Id. at 2800-01 (Breyer, J., dissenting). 
the circumstances of Joshua McDonald (whose request to transfer to a school closer to home was initially declined)." ${ }^{39}$ The incidental cost of using a race-based label in the Seattle and Louisville cases, Justice Breyer adds, "does not approach, in degree or in kind, the terrible harms of slavery, the resulting caste system, and 80 years of legal racial segregation." 40

The consequences of Parents Involved in Community Schools would be even more far-reaching and disquieting if the plurality's arguments in Parts III-B and IV of the Roberts opinion spoke for the Court. They do not. Justice Kennedy's refusal to join these sections of the Roberts opinion tempers the impact of the case. His opinion, along with Justice Breyer's dissent, sets a different course for policy makers to follow in using race-conscious measures to address racial isolation and promote diversity in the nation's public schools.

\section{B. Justice Kennedy's Opinion}

Justice Kennedy's concurring opinion explains his reasons for voting to invalidate the Seattle and Louisville plans. The opinion confirms that he agrees with the Roberts plurality that "in the context of these plans, the small number of assignments affected suggests that the schools could have achieved their stated ends through different means." ${ }^{41}$ Moreover, Justice Kennedy's opinion offers his additional conclusions that the plans failed narrow tailoring because they lacked precision and because the districts

\footnotetext{
39. Id. at 2836 .

40. Id.

41. Id. at 2793 (Kennedy, J., concurring in part and concurring in the judgment).
} 
failed to articulate adequate justifications for their specific racial classifications.

\section{Narrow Tailoring and the Seattle and Louisville Plans}

In criticizing the plans, the Kennedy opinion stresses that "the inquiry into less restrictive alternatives demanded by the narrow tailoring analysis requires in many cases a thorough understanding of how a plan works . . . As part of [the government's burden] it must establish, in detail, how decisions based on an individual student's race are made in a challenged program." "42 The Jefferson County Board of Education failed, in Justice Kennedy's opinion, to meet this basic mandate, because the plan employed "terms so broad and imprecise that they cannot withstand strict scrutiny." 33

Justice Kennedy concluded that the Louisville plan failed "to make clear, for example, who makes the decisions; what if any oversight is employed; the precise circumstances in which an assignment decision will or will not be made on the basis of race; or how it is determined which of two similarly situated children will be subjected to a given race-based decision." ${ }^{44}$ Although the Court's higher education affirmative action cases suggest that transparency in a selection process employing race is not mandated by the Constitution, Justice Kennedy concluded that the Louisville school board had failed to show that its racial classification procedures were narrowed to its specific interests,

42. Id. at 2789 .

43. Id. at 2790 .

44. Id. 
"rather than in the far-reaching, inconsistent, and ad hoc manner that a less forgiving reading of the record would suggest." 45

Justice Kennedy's criticism of the Seattle plan, on the other hand, focuses less on imprecision than on the district's failure to articulate adequate reasons for its racial classifications. In particular, the district's division of students into the categories of "white" and "non-white," according to Justice Kennedy, constituted a "blunt distinction" that did not clearly advance the goals of promoting diversity and reducing racial isolation, especially with a student population with significant numbers of blacks, Asian Americans, Latinos, and Native Americans. Discounting the argument that minority populations in Seattle have been subjected to similar histories of discrimination in education and housing, Justice Kennedy's opinion states that "[f]ar from being narrowly tailored to its purposes, this system threatens to defeat its own ends, and the school district has provided no convincing explanation for its design." 46

\section{Narrowly Tailored Policies and Race-Neutral Alternatives}

Although the Kennedy opinion concludes that the Seattle and Louisville plans fail narrow tailoring analysis, Justice Kennedy does provide three possibilities for upholding $\mathrm{K}-12$ policies that address racial isolation or promote diversity.

45. Id.

46. Id. at 2791 . 


\section{a. "Last Resort" Racial Classifications}

First, Justice Kennedy's opinion indicates in general terms that some racial classifications, if indeed necessary, could satisfy strict scrutiny. His opinion concludes that the Seattle and Jefferson County boards of education "failed to provide the support necessary" to show that there was no other way to avoid racial isolation, but he nonetheless states that racial classifications may be legitimate "if they are a last resort to achieve a compelling interest." 47

Given Justice Kennedy's specific criticisms of the Seattle and Louisville plans, this suggests that he might be willing to uphold race-conscious student assignment policies if they have been thoroughly tested against race-neutral alternatives, if they are sufficiently precise and their implementation process is fully explained, if they take into account the more nuanced racial and ethnic compositions of the districts, and if they significantly affect student assignments and school compositions so that the goals of the plan are clearly attained because of the assignments. Although these characteristics may be difficult to achieve, Justice Kennedy's opinion does leave the door open to limited uses of race in student assignments.

\section{b. Grutter-Type Policies}

Second, Justice Kennedy's opinion states that it is also permissible to employ, "if necessary, a more nuanced, individual evaluation of school needs and student characteristics that might include race as a component. [This] approach would be informed by Grutter, though of course the criteria relevant to

47. Id. at 2792 . 
student placement would differ based on the age of the students, the needs of the parents, and the role of the schools." 48 Although this passage does not provide precise guidance on what might constitute a narrowly tailored policy, it points to the higher education admissions procedures upheld in Grutter $v$. Bollinger as a starting point. Permissible programs might include, for example, a competitive admissions policy for a selective college preparatory high school that employs race as a "plus" factor among other factors designed to promote educational diversity within an entering class. This type of program would have direct parallels to the higher education admissions policies approved under Grutter. What is not entirely clear, however, is how a Grutter-like policybased on individualized consideration of students - might be implemented in non-competitive procedures and across large populations of students and schools.

\section{c. Non-Classification Policies}

Third, Justice Kennedy's opinion articulates a set of K-12 educational policies that do not classify students by race and should not trigger strict scrutiny at all, even though they may involve some attention to race. In one key passage, he states:

In the administration of public schools by the state and local authorities it is permissible to consider the racial makeup of schools and to adopt general policies to encourage a diverse student body, one aspect of which is its racial composition. If school authorities are concerned that the student-body compositions of certain schools interfere with the objective of offering an equal educational opportunity to all of their students, they are free to devise race-conscious

48. Id. at 2793 . 
measures to address the problem in a general way and without treating each student in different fashion solely on the basis of a systematic, individual typing by race.

School boards may pursue the goal of bringing together students of diverse backgrounds and races through other means, including strategic site selection of new schools; drawing attendance zones with general recognition of the demographics of neighborhoods; allocating resources for special programs; recruiting students and faculty in a targeted fashion; and tracking enrollments, performance, and other statistics by race. These mechanisms are race conscious but do not lead to different treatment based on a classification that tells each student he or she is to be defined by race, so it is unlikely any of them would demand strict scrutiny to be found permissible. ${ }^{49}$

The examples offered by Justice Kennedy are already commonly used by school districts and include "magnet schools" that pull in students from surrounding neighborhoods in order to promote greater diversity and establishing school attendance boundaries that cross racially segregated neighborhoods in order to prevent racial isolation.

49. Id. at 2792 (citations omitted). Justice Kennedy's opinion draws parallels between these types of race-neutral policies and electoral districting, an area in which the Court has held that strict scrutiny is not automatically triggered unless race is the predominant factor. Id. 


\section{Approving Compelling Interests: Kennedy and Breyer Opinions}

Beyond the holding of the Court, the multiple opinions of the concurring and dissenting Justices in Parents Involved in Community Schools indicate that school districts and other governmental bodies can still employ race-conscious measures if the underlying goals of the policy are designed to address segregation and to promote diversity. Taking the Kennedy and Breyer opinions together, it is clear that a five-member majority of the current Supreme Court endorses the compelling interests in avoiding racial isolation and in promoting educational diversity in $\mathrm{K}-12$ education.

\section{Kennedy Opinion: Compelling Interests in Avoiding Racial Isolation and Promoting Educational Diversity}

Justice Kennedy declined to join Part III-B of Chief Justice Roberts' opinion, which focuses on the compelling interests of the school districts in promoting diversity and avoiding racial isolation, as well as Part IV of the Roberts opinion. Early in his opinion, Justice Kennedy states: "The plurality opinion is too dismissive of the legitimate interest government has in ensuring all people have equal opportunity regardless of race ... To the extent the plurality opinion suggests the Constitution mandates that state and local school authorities must accept the status quo of racial isolation in schools, it is, in my view, profoundly mistaken." ${ }^{50} \mathrm{He}$ then makes clear that "[d]iversity, depending on

50. Id. at 2791 . 
its meaning and definition, is a compelling educational goal a school district may pursue." 51

Distinguishing the interests asserted by the school districts from an interest characterized by the Roberts plurality as "racial balancing," Justice Kennedy's opinion makes clear that he endorses two closely related compelling interests that could justify narrowly tailored race-conscious policies:

This Nation has a moral and ethical obligation to fulfill its historic commitment to creating an integrated society that ensures equal opportunity for all of its children. A compelling interest exists in avoiding racial isolation, an interest that a school district, in its discretion and expertise, may choose to pursue. Likewise, a district may consider it a compelling interest to achieve a diverse student population. Race may be one component of that diversity, but other demographic factors, plus special talents and needs, should also be considered. ${ }^{52}$

Justice Kennedy thus agrees with the Seattle and Louisville school districts that avoiding racial isolation-which need not be traced to intentional discrimination by governmentcan be a compelling governmental interest. He also distances himself from an argument made by the Roberts plurality that de jure segregation arising through intentional governmental discrimination can be remedied through race-conscious measures while de facto segregation (and resegregation) arising through housing patterns and private discrimination cannot. ${ }^{53}$

51. Id. at 2789 .

52. Id. at 2797.

53. Id. at 2795. Justice Kennedy's opinion states: "The distinction between government and private action, furthermore, can be amorphous both as a historical matter and as a matter of present-day finding of fact." Id. 
Justice Kennedy additionally acknowledges that promoting student body diversity in $\mathrm{K}-12$ education can constitute a compelling interest, but that interest is distinct from an interest in promoting racial diversity alone. In other words, Justice Kennedy endorses an interest in a broad form of educational diversity that encompasses multiple dimensions-one that includes, but is not limited to, race, and that parallels the higher education diversity interest upheld in Grutter v. Bollinger. And consistent with Grutter, the interest in elementary and secondary educational diversity is one that can justify the consideration of race as a "plus" factor in a multifactor selection or assignment process.

\section{Breyer Opinion: A Compelling Interest in Racial Integration}

Justice Breyer's dissenting opinion, which is joined by Justices Ginsburg, Souter, and Stevens, draws an even closer linkage between the Grutter analysis and K-12 education, stating that "[i]n light of this Court's conclusions in Grutter, the 'compelling' nature of these interests in the context of primary and secondary public education follows here a fortiori. Primary and secondary schools are where the education of this Nation's children begins, where each of us begins to absorb those values we carry with us to the end of our days." ${ }^{4}$ Although the vocabulary employed by Justice Breyer to describe the school districts' interests differs somewhat from Justice Kennedy's characterization, the core interests overlap and are similarly compelling. Justice Breyer's opinion goes to great lengths to stress the importance of "an interest in promoting or preserving greater racial 'integration' of public schools," which he describes as the "interest in eliminating

54. Id. at 2822 (Breyer, J., dissenting). 
school-by-school racial isolation and increasing the degree to which racial mixture characterizes each of the district's schools and each individual student's public school experience." 55

Justice Breyer concludes that this interest encompasses (1) a historical and remedial element-an interest in setting right the consequences of prior segregation, (2) an educational elementan interest in overcoming the adverse effects associated with highly segregated schools, and (3) a democratic element-an interest in producing an educational environment that reflects that pluralistic society in which children will live. His opinion states:

The compelling interest at issue here, then, includes an effort to eradicate the remnants, not of general "societal discrimination," .. . but of primary and secondary school segregation ... ; it includes an effort to create school environments that provide better educational opportunities for all children; it includes an effort to help create citizens better prepared to know, to understand, and to work with people of all races and backgrounds, thereby furthering the kind of democratic government our Constitution foresees. If an educational interest that combines these three elements is not "compelling," what is?

Taken together, the Kennedy and Breyer opinions recognize a compelling interest in addressing racial isolation that can justify narrowly tailored race-conscious policies. Both opinions also endorse a diversity interest, although Justice Breyer's "racial integration" interest encompasses the racial diversity interest that Justice Kennedy takes care in his opinion to distinguish from a broader educational diversity interest. At the very least, however,

55. Id. at 2820 .

56. Id. at 2823 . 
language in the Breyer opinion that interprets the Grutter educational interest to be applicable to the $\mathrm{K}-12$ arena a fortiori implies that Justice Breyer and the other dissenting Justices consider promoting educational diversity in $\mathrm{K}-12$ education to be a compelling interest as well.

\section{Summary of Controlling Principles}

With the division of the Justices in Parents Involved in Community Schools, the controlling law is not entirely clear. The analysis in Chief Justice Roberts' opinion where he speaks for the Court provides some key principles, but Justice Kennedy's opinion may ultimately offer the strict scrutiny guidelines that the lower courts will follow in future litigation. His opinion provides details on what may constitute narrowly tailored policies and which types of educational policies should not be subject to strict scrutiny at all; moreover, his compelling interest analysis, taken in tandem with Justice Breyer's opinion, provides the core argument for approving the compelling interests in avoiding racial isolation and promoting educational diversity in K-12 education.

\section{Strict Scrutiny Standard}

The Roberts opinion for the Court makes clear that strict scrutiny is the legal standard to be applied to student assignment policies that employ race as a factor, and those types of plans must be narrowly tailored to a compelling governmental interest. The Roberts and Kennedy opinions also make clear that strict scrutiny applies to voluntary race-conscious plans where there has 
been no past de jure segregation. ${ }^{57}$ The Court acknowledges that context does matter in strict scrutiny analysis, but in the context of $\mathrm{K}-12$ educational policies involving racial classifications, the type of good-faith deference that the Court extended to higher education institutions in Grutter v. Bollinger does not apply.

Although the Court's reasons for invalidating the Seattle and Louisville plans focus on specific problems with the plans, voluntary race-conscious student assignment plans that are similar to either of the plans are subject to strict scrutiny and are likely to be unconstitutional. Justice Kennedy's opinion suggests that there may be very limited circumstances in which carefully crafted racial classifications could satisfy strict scrutiny, if they are demonstrated to be essential to achieving the goals of avoiding

57. Id. It is not clear how the Roberts and Kennedy opinions will affect existing voluntary desegregation plans made pursuant to court settlements or agreements with the Department of Education's Office for Civil Rights where there has been no specific finding or admission by the district of de jure segregation. The Roberts plurality opinion would seem to require strict scrutiny for all plans with no prior showing of de jure segregation, since Chief Justice Roberts gave no weight to the past agreement between the Seattle district and the OCR as a basis for justifying race-conscious remedies for de jure discrimination. Id. at 2761 n. 15 (opinion of Roberts, C.J.). Justice Kennedy's opinion also stresses the de jure-de facto distinction, but his opinion indicates that voluntary desegregation in response to past de jure segregation would be distinct from the voluntary plans at issue in Seattle and Louisville. Id. at 2795 (Kennedy, J., concurring in part and concurring in the judgment). Thus, Justice Kennedy's opinion suggests that voluntary plans obtained through settlements or OCR agreements might be insulated from strict scrutiny. Moreover, the Supreme Court has upheld the application of disparate impact standards to recipients of federal funding assistance "to meet the special needs incident to the elimination of minority group segregation and discrimination among students and faculty in elementary and secondary schools," and "to encourage 'the voluntary elimination, reduction, or prevention of minority group isolation' in such schools . . . " Bd. of Educ. v. Harris, 444 U.S. 130, 132 (1979) (upholding disparate impact standards under Emergency School Aid Act). 
racial isolation or promoting diversity and are demonstrated to be compliant with other narrow tailoring requirements.

\section{Compelling Interests}

Only four members of the Court adopted the view that the school districts' interests in addressing racial isolation and promoting diversity, which the plurality recast as "racial balancing," were not compelling. The remaining Justices would uphold these interests as compelling if a case arose in the futureand if the Court retains its current membership. The Kennedy and Breyer opinions taken together do not establish a formal holding of the Court, but they do provide a strong endorsement of two distinct compelling interests-avoiding racial isolation and promoting educational diversity - that school districts and other governmental bodies can employ to defend their race-conscious policies and that the lower courts can accept in future litigation.

\section{Narrow Tailoring}

In speaking for the Court, the Roberts opinion provides only the most basic guidance on narrow tailoring, and the Court's inquiries in Parents Involved in Community Schools are highly specific to the Seattle and Louisville plans. At a minimum, school districts employing race-conscious assignment policies must have carefully explored race-neutral alternative policies and must demonstrate the necessity of race-conscious plans. What would satisfy a necessity inquiry, however, is not entirely clear. A raceconscious plan must have a significant impact on advancing the school district's interests, and cannot be tied solely to the racial demographics of the district. Language in Justice Kennedy opinion 
further suggests that race-conscious plans should be precisely written and be transparent in their implementation, and that the nuances of the school district's population-specifically, relevant differences among racial and ethnic groups-must be taken into account.

\section{K-12 Educational Policies and Racial Integration: Navigating the Waters}

The Court's rulings in Parents Involved in Community Schools had the immediate consequence of invalidating the plans in Seattle and Louisville. ${ }^{58}$ Student assignment plans in other communities that employ comparable racial classifications and do not address the narrow tailoring concerns of the Court and Justice Kennedy in Parents Involved in Community Schools are most likely unconstitutional as well. The rulings do not completely foreclose the use of racial classifications, but if Justice Kennedy's admonitions are to be heeded, employing racial classifications without some degree of individualized consideration in assigning students must be a policy of final resort. School districts that choose to maintain racial classification systems must be able to answer each of the narrow tailoring concerns raised by the Court and by Justice Kennedy, which may be highly problematic for many districts.

What, then, has the Supreme Court left school districts to employ as constitutionally permissible policies? Five Justices would uphold the interests in avoiding racial isolation and

58. The decision has also cast doubt on an earlier federal court of appeals decision that upheld comparable student assignment policies in Lynn, Massachusetts. Comfort v. Lynn School Comm., 418 F.3d 1 (1st Cir.) (en banc), cert. denied, 126 S. Ct. 798 (2005). 
promoting educational diversity, and nothing in the Kennedy or Breyer opinions suggests that school districts must individually document these interests through a strong basis in evidence in order to satisfy constitutional standards. Instead, the means employed to advance those compelling interests will be central to determining whether school district policies are constitutional. If avoiding racial isolation and promoting educational diversity are compelling interests that can justify a variety of policies, school districts must employ policies that are either (1) raceneutral or (2) race-conscious and compliant with narrow tailoring requirements.

Using Justice Kennedy's concurring opinion as a starting point, there are three sets of potential policies that school districts might adopt:

- "race-neutral" or "race-aware" policies that may take into account race but do not employ racial classifications

- Grutter-style assignment policies that employ race as one of several factors in making student assignments

- racial classifications that are of last resort and can satisfy narrow tailoring

As Justice Kennedy's opinion indicates, the likelihood of unconstitutionality increases as school districts move from raceneutral policies to race-as-plus-factor policies that employ race in a process of individualized consideration, and policies will be presumptively unconstitutional if they employ explicit racial classifications in individual student assignments. The bottom line is that school districts must reexamine their current policies in light of Parents Involved in Community Schools, and they should be prepared to engage in creative policy making that stays within 
constitutional limits but advances the goals of educational diversity and avoiding racial isolation.

\section{A. Race-Neutral and Race-Aware Policies}

Justice Kennedy's opinion offers the following nonexhaustive list of policies that may take race into account but do not classify students by race:

- strategic site selection of new schools

- drawing attendance zones with general recognition of the demographics of neighborhoods

- allocating resources for special programs

- recruiting students and faculty in a targeted fashion

- tracking enrollments, performance, and other statistics by race

These policies typify programs in which school districts can be mindful of racial demographics, patterns of housing segregation, and student enrollment statistics, but do not employ racial classifications on their face. Other race-neutral or race-aware policies not mentioned by Justice Kennedy do exist. For instance, many school districts have employed, with some measure of success, student assignment policies that use criteria such as socioeconomic status to promote racial diversity, because these criteria can closely correlate with race. Another type of raceneutral policy is a lottery or randomized assignment system that may result in assignments and student bodies that parallel districtwide demographics. 
Independent of their actual effectiveness, race-neutral or raceaware policies should satisfy constitutional requirements because they do not employ racial classifications and do not allocate benefits or burdens on the basis of race; they are therefore unlikely to trigger strict scrutiny in the first place. However, districts must also be careful not to overstep the bounds of the Equal Protection Clause by considering or weighing race too heavily. For instance, the Supreme Court's recent case law on legislative districting establishes a trigger for strict scrutiny whenever race is used as the predominant factor in drawing district lines. ${ }^{59}$ Although the law of electoral districting has not been transplanted to school district line drawing, creating school attendance zones with race as the predominant factor might subject a policy to strict scrutiny; while this does not mean that a policy would be unconstitutional, it could be subject to heightened review by the courts if challenged in litigation.

\section{B. Race-as-Plus-Factor Policies}

Justice Kennedy's opinion does not provide detailed guidance on what might be a Grutter-like policy employing individualized consideration of students at the elementary and secondary school levels. His opinion states that "a district may consider it a compelling interest to achieve a diverse student population. Race may be one component of that diversity, but other demographic factors, plus special talents and needs, should also be considered." A clear parallel to admissions in higher education is admission to a K-12 school or program with a competitive selection processfor example, an elite college preparatory high school—in which

59. See Miller v. Johnson, 515 U.S. 900 (1995).

60. Parents Involved in Cmty. Sch., 127 S. Ct. at 2797. 
factors such as grades, test scores, extracurricular activities, residency, and socioeconomic status could be taken into account, along with a student's race or ethnicity, in order to select a student body. However, it is more difficult to envision a holistic, raceas-plus-factor policy involving a large number of students across multiple schools and programs.

Lessons learned in higher education admissions suggest that there are procedures in which multiple criteria can be considered in making selection decisions, including admissions policies used at some of the largest public universities. These types of policies, where race is used as a plus factor along with other individualized factors, could be adapted to apply to enrollment and transfer decisions at the K-12 grade levels. While the design and implementation of these policies in populous and demographically diverse school districts might be challenging, they are not insurmountable. For example, the controlled choice policy struck down in the Seattle school district attempted to employ race as one of a series of tiebreakers (along with residency and sibling status) to determine high school assignments. A constitutionally compliant policy might employ race, residency, sibling status, and a range of additional factors to determine whether an individual student should be assigned to a particular school.

There are, of course, many questions left to be answered. For example, what additional criteria should be included in individualized determinations affecting student assignments? Do these criteria vary by a student's age or grade level? May numerical goals and ranges still be employed to address racial isolation or to promote diversity? If so, how do the specific racial and ethnic demographics within a district affect those goals? Some of these questions may only be answered as school districts take steps to revise their policies and develop new policies, and the legality 
of some programs may ultimately have to be tested through litigation.

\section{Last-Resort Racial Classifications}

The Kennedy opinion still leaves the door open for limited uses of racial classifications that do not employ Grutterstyle procedures, but stresses that there must be a very strong demonstration of necessity before they can be upheld: there must be "some extraordinary showing" 11 of need and "measures other than differential treatment based on racial typing of individuals first must be exhausted." ${ }^{62}$ This language suggests that alternative policies not only need to be seriously considered, they may have to be employed and proved unsuccessful before a racial classification system can be attempted — an especially heavy burden on school districts.

Based on Justice Kennedy's criticisms of the Seattle and Louisville plans, a race-conscious plan would have to have a welldocumented impact on advancing the school district's interests in addressing racial isolation and promoting diversity, but not be so inflexible or burdensome on students that it would violate other narrow tailoring concerns. The racial demographics of the district, including relevant differences among racial and ethnic groups, would have to be taken into account, but not used merely to set goals of racial proportionality. Racial classification plans must also be precisely written and be transparent in their implementation.

61. Id. at 2796 (Kennedy, J., concurring in part and concurring in the judgment).

62. Id. at 2797. 
The door has not been slammed shut on racial classifications in K-12 education, but Justice Kennedy's standards are very difficult to satisfy.

\section{Impact on Equal Protection Doctrine}

When examined in conjunction with other recent Supreme Court cases circumscribing the boundaries of race-conscious affirmative action, ${ }^{63}$ electoral districting designed to promote minority voting rights, ${ }^{64}$ and desegregation policies crafted to enforce the mandates of Brown v. Board of Education, ${ }^{65}$ the outcome in Parents Involved in Community Schools is not altogether surprising. The Court's recent equal protection jurisprudence has become increasingly hostile to race-conscious policy making, and a majority of the current Court is deeply skeptical of policies that employ race, even those that advance important social goals such as integrated public education.

Perhaps the most disturbing aspect of the Seattle and Louisville cases is that several members of the Court have called into question the basic interpretation of Brown, with members of the Roberts plurality arguing for an entirely color-blind interpretation of Brown and the Equal Protection Clause, and going so far as to propose that " $[\mathrm{t}]$ he way to stop discrimination on the basis of race is stop discriminating on the basis of race." 66 Justice Kennedy's opinion tempers that extreme reinterpretation

63. See Adarand Constructors, Inc. v. Peña, 515 U.S. 200 (1995); City of Richmond v. J.A. Croson Co., 488 U.S. 469 (1989).

64. See Miller v. Johnson, 515 U.S. 900 (1995); Shaw v. Reno, 509 U.S. 630 (1993).

65. See Freeman v. Pitts, 503 U.S. 467 (1992); Board of Educ. of Okla. City Pub. Sch. v. Dowell, 498 U.S. 237 (1991).

66. Parents Involved in Cmty. Sch., 127 S. Ct. at 2768 (Roberts, C.J.). 
of the Constitution, but there is still a majority on the current Court that is inclined to limit-if not eliminate-many raceconscious policies that are designed to promote equal opportunity. The rulings in the Seattle and Louisville cases have broader implications for equal protection doctrine, race-conscious policy making, and civil rights litigation, which include some of the following concerns:

\section{A. Limiting Grutter v. Bollinger}

While all of the Justices recognized that Grutter v. Bollinger is good law and a viable precedent, the Parents Involved in Community Schools majority compartmentalized Grutter in significant ways that may limit its applicability outside of higher education. Dismissing any parallels in context between higher education and K-12 education, the majority declared that " $[\mathrm{t}]$ he present cases are not governed by Grutter." ${ }^{67}$ Indeed, Chief Justice Roberts not only distinguished Grutter's higher education context from elementary and secondary education, he argued that higher education is a unique context. Writing for the Court, he stated:

In upholding the admissions plan in Grutter. . . this Court relied upon considerations unique to institutions of higher education, noting that in light of "the expansive freedoms of speech and thought associated with the university environment, universities occupy a special niche in our constitutional tradition." The Court explained that "[c]ontext matters" in applying strict scrutiny, and repeatedly noted that it was addressing the use of race "in the context of higher education."

67. Id. at 2754.

68. Id. (citations omitted). 
The Chief Justice continued: "The Court in Grutter expressly articulated key limitations on its holding-defining a specific type of broad-based diversity and noting the unique context of higher education-but these limitations were disregarded by the lower courts in extending Grutter to uphold race-based assignments in elementary and secondary schools." ${ }^{\prime 9}$ He then concluded that Grutter did not apply at all to the Seattle and Louisville cases. ${ }^{70}$

By portraying higher education admissions as sui generis, Chief Justice Roberts' opinion leaves little doubt that he is attempting to confine Grutter's value as a precedent-not only for K-12 education but for other settings where race-conscious policies are in use. Both Justice Kennedy and Justice Breyer rely on Grutter in large part to defend their recognition of diversity as a compelling interest in K-12 education, so the language in Chief Justice Roberts' opinion is undermined in practical terms by the other Justices' opinions. Nonetheless, language in the Roberts opinion in Parents Involved in Community Schools may lead other courts to discount Grutter as an applicable precedent in key areas outside of higher education, such as employment in the public schools and other governmental jobs, ${ }^{71}$ where diversity-based policies have been deployed.

69. Id.

70. See Id.

71. A discussion of the impact of Parents Involved in Community Schools on Title VII of the Civil Rights Act of 1964 and other laws that affect privatesector employment is beyond the scope of this analysis. The law governing race-conscious affirmative action in private employment differs in important ways from the Court's equal protection jurisprudence on affirmative action, but the reasoning in Parents Involved in Community Schools may ultimately have significant effects on how the courts evaluate diversity-based programs interests in other sectors. 


\section{B. Context and Strict Scrutiny Analysis}

In upholding the University of Michigan's law school admissions policy, the Grutter Court stated that "[c]ontext matters" in applying strict scrutiny; moreover, the Court ruled, "[n] ot every decision influenced by race is equally objectionable, and strict scrutiny is designed to provide a framework for carefully examining the importance and sincerity of the reasons advanced by the governmental decisionmaker for the use of race in that particular context." context of higher education, where academic freedom and First Amendment considerations were also implicated, the Court employed a careful, but less searching review under strict scrutiny and deferred in important ways to institutions of higher learning. The Grutter Court did not, for example, require a strong basis in evidence for universities to justify their interest in diversity, and the Court presumed good-faith compliance in a number of its narrow tailoring inquiries.

The Court in Parents Involved in Community Schools distinguished higher education from $\mathrm{K}-12$ education, and employed a strict scrutiny standard that offered no deference to the school districts. Consequently, the Court's review was considerably more skeptical than the standard adopted in Grutter. For instance, the majority did not accept the good-faith attempts of the Seattle school district to consider race-neutral alternatives, and ignored the lengthy history of past desegregation efforts in both Seattle and Louisville that could help establish the context in which the policies arose.

Part IV of Chief Justice Roberts' plurality opinion is emphatic in its rejection of a relaxed strict scrutiny, proposing

72. Grutter, 539 U.S. at 327. 
that earlier cases "reject the argument that motives affect the strict scrutiny analysis" and that deference to local school boards "is fundamentally at odds with our equal protection jurisprudence."73 His opinion is thus in direct opposition to Justice Breyer's contextual approach to the Seattle and Louisville plans, where he and the other dissenting Justices would have employed a careful but more relaxed scrutiny to uphold the plans. Justice Breyer's analysis takes into account both the motives of the policy makers and the courts' traditional deference to local governmental decision making. Justice Breyer accordingly characterized Roberts' standard of review as one that is "fatal in fact across the board." "4

By failing to extend a contextual analysis to the school districts' policies in Parents Involved in Community Schools-what Justice Stevens described in his dissent as "a wooden reading of the Equal Protection Clause"75 — the majority revealed its cynicism toward race-conscious policies and its unwillingness to modify strict scrutiny in order to take into account important factual and institutional differences. The Court did not say that context should never matter, which would have effectively confined contextual deference to Grutter itself, but the Court offered no guidance on when and how context should make a difference in the future.

\section{Narrow Tailoring and Race-Neutral Alternatives}

Neither Chief Justice Roberts' plurality opinion nor Justice Kennedy's opinion in Parents Involved in Community Schools radically changes the law of narrow tailoring. Yet, their

73. Parents Involved in Cmty. Sch., 127 S. Ct. at 2764, 2766.

74. Id. at 2817 (Breyer, J., dissenting).

75. Id. at 2798 (Stevens, J., dissenting). 
inquiries under narrow tailoring reflect an opposition to racial classifications that may make future inquiries especially rigorous. In writing for the Court, Chief Justice Roberts' narrow tailoring analysis focused heavily on whether the policies were necessary to advance a compelling interest. In assessing the necessity of the plans, Chief Justice Roberts approached the inquiry in a backhanded way: he inferred that they were not necessary because they employed race ineffectively and the objectives of the policy could have been accomplished through other means. Similarly, Justice Kennedy criticized the Louisville plan for its lack of precision and transparency in making race-conscious decisions. Yet, in order to be consistent with case law such as Grutter, the districts' plans intentionally downplayed race as a factor in order to comply with the requirements that they be flexible and not unduly burden non-minority students. In the future, navigating safe waters between flexibility and limited burdens on the one hand and effectiveness and necessity on the other hand may prove to be hazardous for policy makers attempting to comply with narrow tailoring.

Although Justice Kennedy's opinion offers a number of raceneutral and race-conscious policies that that he might uphold as constitutional, his narrow tailoring analysis in Parents Involved in Community Schools is exacting and implies that he may only accept overt racial classifications when there is an extraordinary showing of need. Justice Kennedy may insist in the future that before race-conscious policies can be employed, "measures other than differential treatment based on racial typing of individuals first must be exhausted." 76 This language suggests that policy makers may only be able to employ explicitly race-conscious

76. Id. at 2797 (Kennedy, J., concurring in part and concurring in the judgment). 
policies after they have already attempted race-neutral policies, which is a significantly higher burden than merely having to go through a good-faith consideration of race-neutral policies. Both Justice Kennedy and Chief Justice Roberts have elevated the role of race-neutral alternatives as a means for striking down racial classifications, and their standards, if adopted in later cases, may prove to be unreachable by many policy makers.

\section{Conclusion}

The Supreme Court's ruling in Parents Involved in Community Schools marks a major shift in its equal protection jurisprudence and its dedication to defending equal educational opportunity. The case demonstrates that the Court, like the American public, remains deeply divided on questions of race and race-conscious policy making. Thus even today, over fifty years after the Court's ruling in Brown v. Board of Education, the goals and methods of achieving equality espoused in Brown are still hotly contested. The impact of the Seattle and Louisville cases on school assignment policies will be significant, but the legal mandates of the case do not foreclose creative and dedicated policy making designed to promote diversity and to avoid racial isolation in the nation's schools. Nothing in the Court's decision should diminish the integration ideal implicit in Brown. The Seattle and Louisville cases should instead provide the public and government at all levels with a strong impetus to further advance equality and to promote educational opportunities within the bounds of the Constitution. 